\title{
Credit Risk and Shareholders' Value in a Developing Economy: Evidence from Pakistani Banking System
}

\author{
${ }^{*}$ Ahmed Arif ${ }^{1}$, Afsheen Abrar ${ }^{1}$, Mohammad Afzal ${ }^{2}$ \\ ${ }^{1}$ Shaheed Zulfiqar Ali Bhutto Institute of Science and Technology, Islamabad, Pakistan \\ ${ }^{2}$ Comsats Institute of Information Technology, Islamabad, Pakistan \\ *lakhvera@gmail.com
}

\begin{abstract}
The present study examines the role of credit risk in value creation process in banking system of Pakistan. This study here develops a conceptual model with three antecedents to credit risk. These antecedents are loan loss provision, advances, and capital adequacy ratio. The study analyzes the impact of these antecedents on accounting return on equity (ROE) and market return on shares (ROS). The data come from 20 banks listed on Karachi Stock Exchange (KSE) for 2004-2009. The study includes panel data analysis to analyze the relationship between the selected variables. The results of this study expose a minimal role of credit risk in value creation process in banking system of Pakistan. The results further reveal that banks with higher advances in their portfolio are successful in getting the confidence of shareholders.
\end{abstract}

Keywords: Credit risk; Shareholders' value; Banking sector; Loan loss provision; Capital adequacy ratio; Return on equity.

\section{Introduction}

Traditionally, channelizing the flow of funds has been the key function performed by commercial banks. The banks take the funds from the depositors and use them in lending activities (Chaplin et al., 2000). According to Allen \& Santomero (1996), banks play the role of financial intermediaries. They act as a bridge between the cash starved, and cash enriched individuals. An active and efficient banking system augments the growth of industry in the economy. Banks also play the role of agent between the two parties in many transactions. They play the role of guarantors to facilitate the finalisation of different contracts. They provide different financial products including credit cards, saving accounts, personal loans, home loans etc. It can be observed that the nature of banking business is quite complex and risky (Al-Tamimi \& Al-Mazrooei, 2007). The business operations, detailed above, expose the banks to a large number of risks. Among all the risks faced by a financial institution, credit risk is the most significant risk (Goodhart, 2005; Fatemi \& Fooladi, 2006; Akhtar, 2007; State Bank of Pakistan (SBP), 2009) due to the large-scale credit operations carried out by the bank. The banks failing to mitigate and manage the credit risk may pay a high cost for the same in the shape of the bankruptcy. Therefore, measurement and mitigation of credit risk in financial institutions is going to be a burning issue for policy makers, practitioners and academician with every passing day.

According to Akhtar (2007), credit operations are the main source of income for banks. However, these operations are also a primary source of risk. Credit risk is the primary risk faced by financial institutions especially banks since the early days of their intermediation. The risk officers of a bank especially focus on mitigating credit risk, which can be a source of massive loss to the banking system. The large number of loan defaults may put the survival of the bank at stake. This may become a worrisome situation for the management and shareholders. The prime causes of a banking crisis concern slack regulations for the issuance of credit to borrowers, mediocre level of risk management and lack of attention to the changing economic conditions. These factors may deteriorate the position of the borrowers of a bank (BCBS, 1999; Baele, et al., 2005) and exacerbate their inability to pay back their obligations towards the bank. Succession of financial crises has resulted in discovering new techniques for mitigation of credit risk, particularly after the recent financial crisis of 2007-2008. The reliability of different financial instruments, like asset put options, total-return swaps, credit-linked notes and collateralized debt obligations, used for credit risk assessment have become suspicious (Angkinand et al., 2010).

The regulators of the banking system are always afraid of the contagion effect, largely caused by the credit risk. Collapse of one institution may affect others along with the entire financial system of the economy. According to Goodhart (2005), credit risk does not tend to be systematic in the banking system. 
The failure of one bank will drive other banks to the brink, through reputation effects and interconnections. The world economy has experience this in different financial crises, when one collapsing bank caused the drowning of many other banks along with it e.g. the failure of BCCI in U.K. and Lehman Brothers in U.S.A. The banks in Pakistan are facing new forms of risks that have changed the nature of their exposure to risks. The credit risk relating to corporate assets changes with the size and complexity of the business. The risk exposure of banks has considerably increased because of their involvement in other businesses like mortgages and personal finance (Akhtar, 2007). According to Pakistan's central bank, SBP (2009-2010), the loss ratio caused by credit risk increased in the financial year 2010. Although gross NPLs (non-performing loans) have slowed down, the increase in losses creates worrisome situation for the banks (see Figure 1).

\section{Figure 1: Category Wise Movement of Gross NPLs (July-Dec)}

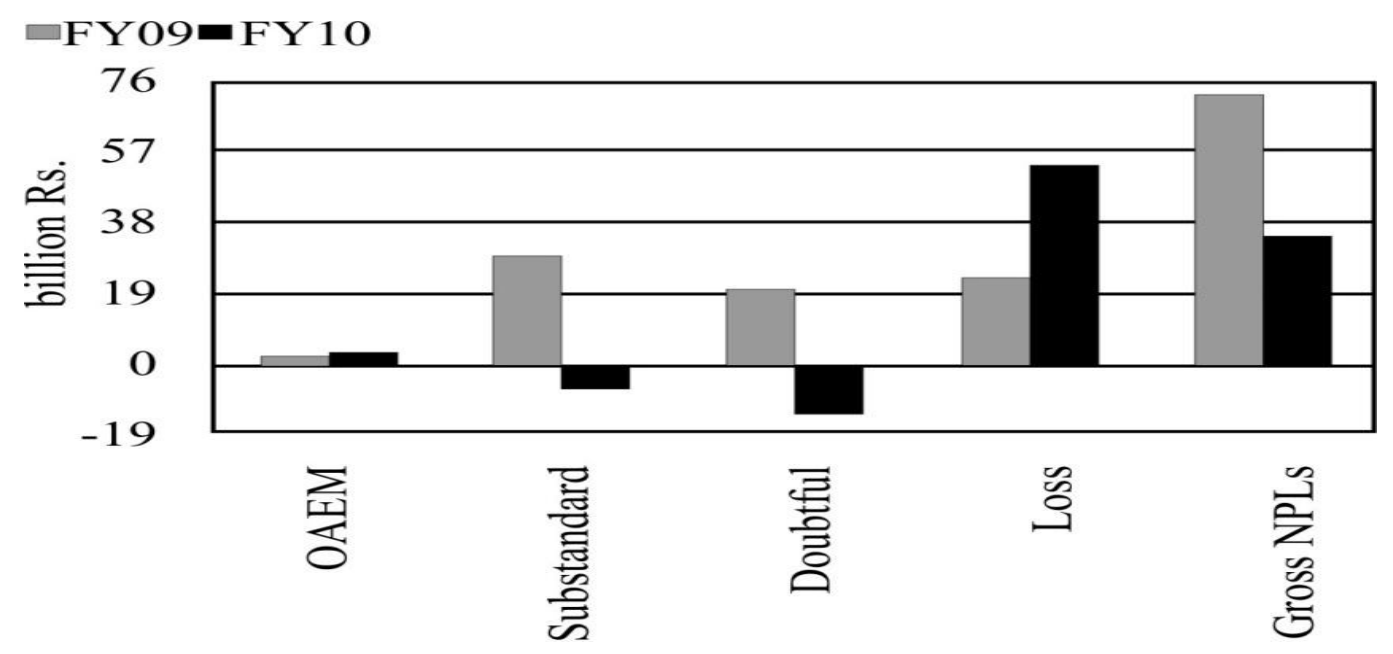

The purpose of the present study is to assess the impact of credit risk on shareholders' value. Pagano (2001) states that risk management are an essential function, performed by the banking system, to create value for shareholders and their respective customers. The financial management concepts also link the risk management with the shareholders' wealth maximization. The bank should only perform risk management activities if they help to increase shareholders' wealth (Ali \& Luft, 2002). Hence, risk management system is presumed to facilitate the value creation process in any organization, either banking or non-banking entity. The past researchers (Carty, 2000; Al-Tamimi \& Al-Mazrooei, 2007) state that empirical work relating risk management with shareholders' value is limited, and most of the work in this area is theoretical in nature. This situation necessitates empirical studies for the evaluation of linkage between different risks and shareholders' value. The present study focuses credit risk only being the most significant risk in the banking system. The credit operations are the primary source of income for a commercial bank (Ojo, 2010). However, these operations can have a detrimental effect on the stability of a bank, due to poor risk management. This paper has analysed the effect of the risk involved in these credit operations on shareholders' value. This study guides the shareholders who are concerned about the credit operations of banks. It clarifies the role of credit risk in the variations in returns.

This study follows a novel approach. The previous studies focus on the risk management tools (Fatemi \& Fooladi, 2006), the performance of the banking system either through cost and production function (Berger \& Humphrey, 1997), accounting ratios (Sensarma \& Jayadev, 2009) and performance of the banking system through its effectiveness using the risk quantification methods (Altman, et al., 1998). This study attempts to incorporate all the above functions and evaluates the effect of different antecedents of credit risk on shareholders' value. Therefore, this study follows a novel approach. The study here incorporates the role of two moderating variables (market and economy). The study has following objectives: The study has following objectives: (a) Find an empirical evidence of the association between credit risk and shareholders' value (b) Investigate the role of credit risk in variation in stock returns (c) analyse the role of economy and market in variation of share holder's returns. 


\section{Literature Review}

Credit risk is the major risk for commercial banks and it requires very vigil oversight and extensive policy debate. It is typically defined as the risk of loss resulting from failure of obligors or borrowers to honour their payments (Pesaran \& Schuermann, 2003). Credit risk is most simply defined as the potential that a bank borrower or counterparty will fail to meet its obligations in accordance with agreed terms (BCBS, 1999). Lopez (2001) defines credit risk as the risk that the value of a loan (or more generally, a stream of debt payments) will decrease due to a change in the borrower's ability to make payments, whether that change is an actual default or a change in the borrower's probability of default. Banks may use different methods for the assessment of credit risk in the different exposure. It is very important for every bank to conduct a periodical review, at least on quarterly basis, to evaluate the performance of its corporate credit portfolio borrower-wise by size, system, and collateral category including analysis of major limits and lines granted deviations from the bank's loan strategy, scale and development of new business (SBP, 2009).

Honohan and Laeven (2005) state that increase in inflation unpredictability and precariousness of exchange rate after 1971 has increased the susceptibility of banking system more than any other sector of the economy. The frequency and severity of banking crises multiplied during the last quarter of the previous century. The costs of these banking crises have been incredibly large which has not only been borne by its shareholders but also by the governments and taxpayers. In addition to the fiscal cost, collapse of large banks across the World has contributed to longer economic downfalls and worsening poverty across the globe. Despite the presence of some advanced models, it is not an easy task to predict systemic banking crises, emanating mainly from credit risk. The health of a bank's loan portfolio can be affected by the variation in the credit risk affecting the overall performance of the bank (Sufian, 2009). This argument finds support by Duca \& McLaughlin (1990) who stressed that a large-scale variation in bank's profitability can be ascribed to variations in credit risk. Banks that are largely exposed to credit risk face reduction in their profitability. Miller \& Noulas (1997) are of the view that so long as the banks have exposure in risk loans, NPLs tend to rise which ultimately reduces the profitability of the bank. Baele et al. (2006) argue that the banks relying more on non-interest income, have more volatility in their stocks and high betas.

Sometimes managers engage in the risk management practices that are not aligned with the shareholders' wealth maximisation hypothesis. When the managers' interests are in conflict with that of shareholders, they practice the risk management strategies in order to enhance their own personal wealth and to take the benefit of the effects of changes in the prices of commodities, interest rates or foreign currency values. Managers may take these types of steps without taking into consideration the shareholders' wealth maximisation hypothesis (Baele et al., 2006; Fatemi \& Fooladi, 2006). An effective credit risk management system addresses four areas (i) establishing an appropriate credit risk environment; (ii) operating under a sound credit granting process; (iii) maintaining an appropriate credit administration, measurement and monitoring process; and (iv) ensuring adequate controls over credit risk (BCBS, 1999). Credit risk is usually assessed on the previous trends and evidence that are anecdotal in nature (Kao, 2000). The researchers and practitioners have developed a number of tools for mitigation and management of credit risk. Keasey \& Veronesi (2008) call it an illusion that the newly developed tools for credit risk management are effective in assessing and pricing the credit risk. They call it an illusion because the effectiveness of the developed techniques is largely depending on the available data. They give the example of self-certification and inflated values on property to support their argument. All the credit risk management techniques are useless if managers of a bank do not assess the authentication of the data provided by borrowers.

According to Altman, Caouette, \& Narayanan (1998), the economic environment plays an important role in credit risk mitigation. The credit risk mitigation and management system needs to be more vigilant in poor economic conditions. The economic uncertainty stresses for a more sophisticated and sensitive credit risk mitigation system. Credit risk faced by the banking system varies with the macroeconomic conditions. Usually in a high growth economy, banks enhance their lending (Sufian, 2009). Banks lend to earn profit, but this situation is highly associated with the credit risk. Credit risk may overwhelm a bank if there are sudden undesirable changes in the economy. This situation may cause devastating results for the institution, affecting its stock returns and profitability (Baele, et al., 2005). Concomitantly, an effective credit risk management system should not only reduce the chances of loss emanating from the credit risk, but also maximize a bank's risk adjusted rate of return, by confining the credit risk exposure within an 
acceptable range (BCBS, 1999). Baele et al. (2005), further emphasise that in time of recession it becomes more difficult for a bank to assess the credit worthiness of a borrower. The downturns in the economy negatively affect the cash flows of borrowers, which may cause the default of bank loans. In this situation, assessment of loan applicants can be subjective, which exacerbate the uncertainty of net present value (NPV) of different projects. Moreover, the value of the companies and collateralised assets also falls and credit worthiness of the borrowers may deteriorate due to the reversal of business cycles.

Keasey and Veronesi (2008) illustrate that when the economy is growing, there is high competition in the credit market. In this highly competitive environment, banks try to capture more business while offering a wide range of products and low price as compared to their competitors. The risk in this situation may not be properly assessed and priced. The loans may be issued to the borrowers whose credit worthiness is not authenticated. This situation gives rise to credit risk which may cause a massive loss to the bank if its borrowers default, affecting the shareholders' value. A bank can summarize its risk profile its loss distribution, i.e. distribution of losses resulting in different economic conditions. Credit portfolio models seek to precisely engender that distribution, often through simulation, so that a bank may set the required level of capital to survive in losses to a specific level of confidence that is a tail region in the loss distribution. Most credit portfolio models try to link the portfolio loss distribution to prevailing economic conditions; they are different in their linkage (see Figure 2). However, with only one exception this linkage is to a single, unobserved systematic risk factor (Pesaran \& Schuermann, 2003).

\section{Figure 2: A General Framework of Credit Risk Model (Pesaran \& Schuermann, 2003) Conditional Default Rate}

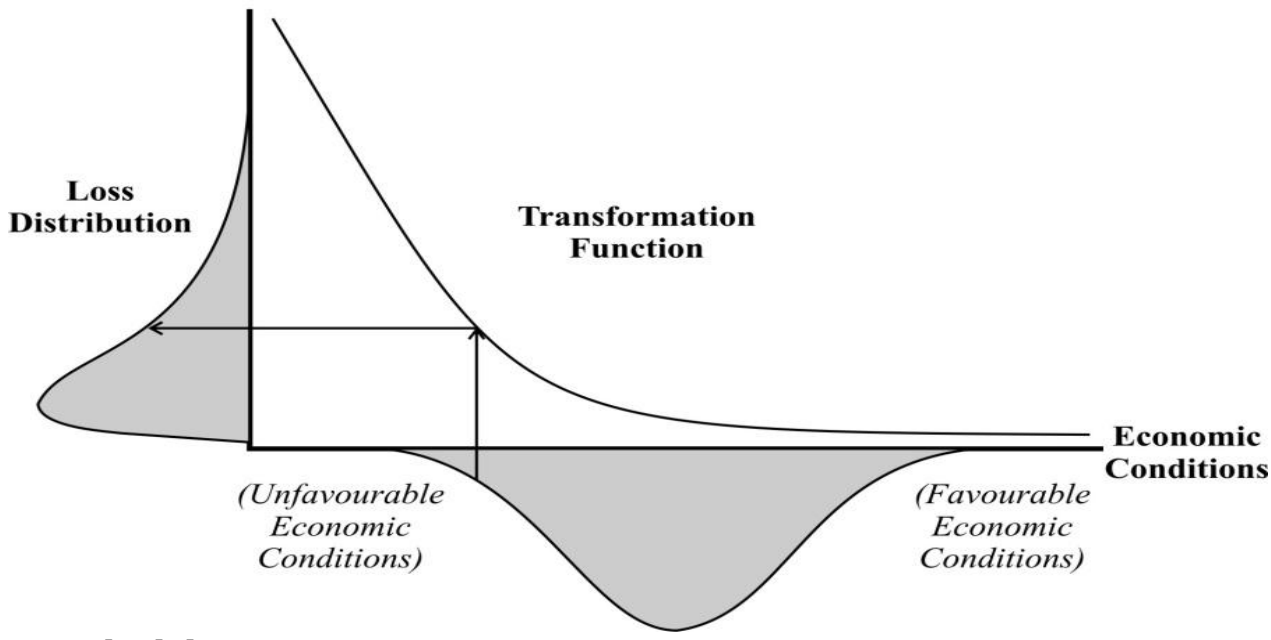

\section{Methodology}

This section explains the theoretical framework and the data employed in this study.

Theoretical Framework: This study develops a framework encompassing three antecedents of credit risk accompanied by other important factors that affect the shareholders' value. The objective is to evaluate the impact of credit risk on shareholders' wealth, which is measured by ROE (return on equity) and ROS (return on shares). The current study treats credit risk as an independent variable. Market and economy are proxied by the KSE (Karachi stock exchange) 100 index and gross domestic product (GDP) that are main indicators of health of an economy. The study assumes that these two factors have a vital impact on shareholders' value. The shareholders are interested to have an increase in their shares value as well as overall return on equity. According to Fatemi \& Fooladi (2006), banks should only exercise risk management practices if they help to increase the shareholders' value. An increase in shareholders' value not only increases the confidence of existing shareholders but also attracts new investors. Therefore, this study takes two dependent variables (ROE and ROS).

ROE is defined as follows:

$\mathrm{ROE}_{\mathrm{it}}=\mathrm{ROA}_{\mathrm{it}} * \mathrm{EM}_{\mathrm{it}}$

Where

$\mathrm{ROE}=$ ratio of profit after tax to total equity

ROA = ratio of net-interest income plus non-interest income less provisioning to total assets

$\mathrm{EM}=$ ratio of total assets to total equity 
A bank can increase ROE by increasing net-interest income and non-interest income and by decreasing provisioning. Banks largely depend on credit operations as major sources of income. Hence, interest income plays a vital role in increasing ROE. Banks' ROE falls when provisioning is high, as in case of high credit risk (Sensarma \& Jayadev, 2009). Subsequently, the credit risk has a strong influence in determining the overall ROE. ROS represents the market return on the shares. This return has been calculated with the help of daily stock prices. The data has been obtained from the KSE online data stream. ROS has been calculated as follows:

$$
\operatorname{ROS}_{\mathrm{it}}=\frac{\Sigma\left\{\mathrm{Ln}\left(\mathrm{P}_{\mathrm{it}} / \mathrm{P}_{\mathrm{it}-1}\right)\right\}}{\mathrm{n}}
$$

The product of the credit risk in banking system is NPLs. NPLs start increasing in times of high credit risk, (Miller and Noulas, 1997). This study measures the credit risk with the help of loan loss provision over total loans ratio (LLP/total loans) (Sufian, 2009). An increase in this ratio shows that the bank is facing higher level of credit risk and vice versa. The major source of income for a bank is its credit operations, generating interest income (Akhtar, 2007). However, these credit operations are not useful in enhancing shareholders wealth if credit worthiness of the borrowers is not properly assessed, as in case of the conflict of interest between managers and shareholders (Fatemi \& Fooladi, 2006). If a manager issues credit to a borrower whose credit worthiness is doubtful, then instead of generating income, it may cause a massive loss to the bank and shareholders. Thus, the assumption that credit operations always generate income for the shareholders may not hold true. The banks are now diversifying to reduce their reliance on interest income. However, interest income remains a major source of income for banks. This study attempts to find an empirical association between the advances issued by the bank and shareholders' wealth. The ratio of advances/total assets ratio is used for this purpose.

According to the Basel II, capital adequacy ratio (CAR) should not fall under a certain level (8\%). CAR helps banks to manage credit risk and enable the financial institutions to bear the shocks caused by the credit risk. However, its impact on shareholders' wealth requires assessment. While examining all the above factors, one cannot ignore the overall market and economy. A bank enhances its credit operations when the economy is growing (Sufian, 2009). This helps to increase the interest income. The bank also experiences a reduction in its NPLs in a growing economy, which decreases the overall provision and increases ROE. BCBS (1999) emphasizes that loss of a bank caused by credit risk increases because of poor attention to fluctuating economic conditions. Market plays an important role in determining the shareholders' value. It is difficult for a single firm to show growth when the whole market is in a depression. Based on above discussion, the following two models specify the relationships between the respective variables:

$Y_{1 i t}=\alpha-\beta_{1} X_{1 i t}+\beta_{2} X_{2 i t}+\beta_{3} X_{3 i t}+\beta 4 G D P_{t}+\mu_{i t}$

$\mathrm{Y}_{2 \mathrm{it}}=\alpha-\theta_{1} \mathrm{X}_{1 \mathrm{it}-1}+\theta_{2} \mathrm{X}_{2 \mathrm{it}-1}+\theta_{3} \mathrm{X}_{3 \mathrm{it}-1}+\theta_{4} \mathrm{GDP}_{\mathrm{t}}+\theta_{5} \mathrm{KSE}_{\mathrm{it}}+\mu_{\mathrm{it}}$

\author{
Model I \\ Model II
}

Where:

$\mathrm{t}=$ time period 2004-2009

$\mathrm{t}-1$ = lagged year

$\mathrm{i}=$ cross section $\mathrm{i}=\mathrm{I}, 2 \ldots 20$

$\mathrm{Y}_{1 \mathrm{it}}=$ return on equity in year $\mathrm{t}$

$\mathrm{Y}_{2 \mathrm{it}}=$ return on shares in year $\mathrm{t}$

$\mathrm{X}_{1}=$ loan loss provision/advances in year $\mathrm{t}$

$\mathrm{X}_{2}=$ advances $/$ total assets in year $\mathrm{t}$

$\mathrm{X}_{3}=$ capital adequacy ratio (CAR) in year $\mathrm{t}$

$\mathrm{X}_{\mathrm{t}-1}=$ loan loss provision/advances in year $\mathrm{t}-1$

$\mathrm{X}_{2 \mathrm{t}-1}=$ advances $/$ total assets in year $\mathrm{t}-1$

$\mathrm{X}_{3 \mathrm{t}-1}=$ capital adequacy ratio in year $\mathrm{t}-1$

GDP = current Pakistan GDP in year $\mathrm{t}$

$\mathrm{KSE}=\mathrm{KSE} 100$ index growth in year $\mathrm{t}$

$\mu_{\mathrm{it}}=$ error term in year $\mathrm{t}$

The study first estimates these equations with OLS (ordinary least square) and then use panel data analysis techniques due to degrees of freedom and other problems with OLS. Model II contains lagged values for LLP, Adv and CAR. It is assumed that an investor, while making the investment decision in the shares of a bank, evaluate the credit risk faced by the bank in the previous years. The investors are 
reluctant to make the investment in a bank having high credit risk. Consequently, it affects the trading of shares in the market. The price of shares goes down because of the decrease in demand. This situation affects the market return on shares for the existing stockholders.

Data: Karachi Stock Exchange (KSE) has a listing of 27 banks including 2 Islamic banks, 2 thrifts and 23 conventional banks. Islamic banks and thrifts have a different risk management structure. Therefore, the current study focuses on conventional banks only. Data come from 20 banks for 2004-2009. Data availability dictates the choice of 20 banks that account for majority of the total assets of the Pakistani banking system. The data for LLP, total assets, advances, CAR and ROE come from annual reports of banks (financial statements and their notes), whereas, data for return on shares is from KSE. Capital market data has preference over the accounting data because the stock prices are forward-looking that identify the prospective performance and impact of risk associated with different strategic choices (Baele, et al., 2006). The study takes KSE 100 Index as proxy of market. Panel data analysis is preferred technique for this study to overcome the problems of small sample size and degrees of freedom. The panel data provide more variability and reduce the chances of colinearity among the variables. The panel data are also helpful in detecting and measuring the effects that are difficult to measure with the simple cross section or time series data (Baltagi, 1995).

The widely used techniques for the analysis of panel data are Fixed Effect Model (FEM) and Random Effect Model or Error Correction Method (ECM) (Baltagi, 1995; Gujarati \& Sangeetha, 2004; Brooks, 2008). ECM is more appropriate technique when the sample is randomly selected from the population, but FEM is preferred if the sample constitutes the entire population (Brooks, 2008). The sample of this study almost consists of the entire population of banks listed on KSE. Therefore, FEM is applied for the analysis of our data. FEM allows for the varying intercepts for cross sections assuming the effects are fixed over time (Gujarati \& Sangeetha, 2004).

\section{Results and Discussion}

This section explains the results of the statistical tests applied the data and the discussion based on the obtained results.

Results: This study examines two models with two different DVs, as specified above, with same set of IVs. OLS technique used to examine the relationship. The results of OLS are as follows:

Model I

\begin{tabular}{|c|c|c|c|}
\hline \multicolumn{4}{|c|}{$\hat{Y}_{1 i t}=-1.14-0.29 \mathrm{X}_{1} \mathrm{it}_{+}+1.87 \mathrm{X}_{2 \mathrm{it}}+1.6 \mathrm{X}_{3 \mathrm{it}}+0.05 \mathrm{GDP}_{\mathrm{t}}+2.03$} \\
\hline $\mathrm{se}=(1.23) \quad(0.99)$ & $(1.73)$ & $(2.15)$ & $(0.08)$ \\
\hline$t=(-0.93)$ & $(1.08)$ & $(0.74)$ & $(0.65)$ \\
\hline$R^{2}=0.0147$ & & urbin $\mathrm{W}$ & 1.04 \\
\hline
\end{tabular}

Model II

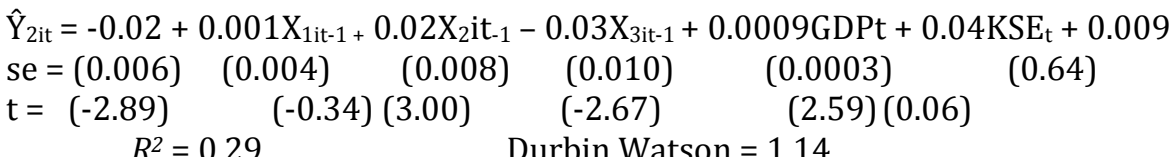

The results of OLS are statistically insignificant and not reliable. Hence, FEM obtain more reliable results for the panel data under study. Table 1 shows the results of FEM, applied on Model I. Table 1 reveals the effect of three IVs along with one moderator on the dependent variable (ROE). The overall explanatory power of the model is $32.83 \%\left(R^{2}=0.3283\right)$. The two IVs LLP/Adv $\left(\mathrm{X}_{1}\right)$ and $\mathrm{Adv} / \mathrm{T}$.Assets $\left(\mathrm{X}_{2}\right)$ negatively affect the dependent variable (ROE). Although the $t$-statistics shows the insignificance of these relationships $\left(-0.28\right.$ and -0.02 respectively for $\mathrm{X}_{1}$ and $\left.\mathrm{X}_{2}\right)$, but it can be partially accepted that these two variables are negatively related with ROE. Any increase in these two variables may lead to a decrease in ROE. Especially, LLP can adversely affect the ROE. The results show that one-degree change in LLP can bring 1.10-degree negative change in ROE. The advances have also a negative effect on ROE but this effect is minimal (3\%). 
Table 1: Fixed Effect Model I

\begin{tabular}{lllll}
\hline Variable & Coefficient & Std. Error & t-Statistic & Prob. \\
\hline $\mathrm{C}$ & -0.16 & 1.28 & -0.12 & 0.90 \\
$\mathrm{X}_{1}$ & -1.10 & 3.88 & -0.28 & 0.78 \\
$\mathrm{X}_{2}$ & -0.03 & 1.85 & -0.02 & 0.99 \\
$\mathrm{X}_{3}$ & 1.75 & 3.16 & 0.55 & 0.58 \\
$\mathrm{GDP}$ & 0.04 & 0.07 & 0.57 & 0.57 \\
R-squared & 0.3283 & Mean dependent var. & 0.2824 \\
Adjusted R-squared & 0.1674 & S.D. dependent var. & 2.0086 \\
S.E. of regression & 1.8327 & \multicolumn{2}{l}{ F-statistic } & 2.0405 \\
Durbin-Watson stat & 1.7839 & \multicolumn{2}{l}{ Prob. (F-statistic) } & 0.0086 \\
\hline
\end{tabular}

Dependent Variable: Return on Equity (Y1)

Two of the variable $\mathrm{X}_{3}$ (CAR) and GDP are positively associated with the ROE, as shown by their coefficients. CAR can cause 1.748-degree change in ROE and GDP can bring .0396-degree change in ROE with one-degree change in it. These two relations are again insignificant as shown by t-statistics i.e. 0.553 and 0.57 respectively.

Table 2: Fixed Effect Model II

\begin{tabular}{lllll}
\hline Variable & Coefficient & Std. Error & t-Statistic & Prob. \\
\hline $\mathrm{C}$ & -0.02 & 0.00 & -4.68 & 0.00 \\
$\mathrm{X}_{1}(-1)$ & 0.0035 & 0.01 & 0.26 & 0.79 \\
$\mathrm{X}_{2}(-1)$ & 0.0113 & 0.00 & 1.65 & 0.10 \\
$\mathrm{X}_{3}(-1)$ & -0.0023 & 0.01 & -0.19 & 0.85 \\
$\mathrm{GDP}$ & 0.0032 & 0.00 & 5.38 & 0.00 \\
$\mathrm{KSE}$ & 2.69 & 0.75 & 3.61 & 0.00 \\
R-squared & 0.7688 & Mean dependent var. & -0.0034 \\
Adjusted R-squared & 0.6948 & \multicolumn{2}{l}{ S.D. dependent var. } & 0.0110 \\
S.E. of regression & 0.0061 & \multicolumn{2}{l}{ F-statistic } & 10.3901 \\
Durbin-Watson stat & 2.7312 & Prob. (F-statistic) & 0.0000 \\
\hline
\end{tabular}

Dependent Variable: Return on Shares (Y2)

Table 2 shows the results of FEM applied to Model II. The dependent variable is ROS here and the independent variables are LLP/Adv., Adv/T.Assets and CAR. GDP and KSE are two moderators is this equation. The value of $R^{2}$ is 0.7688 , which shows the explanatory power of the model. The variation in the value of ROS caused by the set of IVs and moderators is $76.88 \%$. The signs of the coefficients of $\mathrm{X}_{1}$ and $\mathrm{X}_{2}$ are positive, revealing a positive relationship with ROS. The $t$-statistics for these coefficients are also insignificant again ( 0.26 and 1.65 respectively). The coefficient for $\mathrm{X}_{3}$ has surprisingly a negative sign revealing a negatively relationship with the ROS but $t$-statistics is insignificant $(-0.19)$. The two moderators, GDP and KSE, positively relate with ROS. The $t$-statistics for both of these variables is significant (5.38 and 3.61 respectively).

Discussion: Examining the relationship between credit risk and ROS provides very interesting findings. LLP has a positive association with ROS. The investors prefer the banks having more risk taking behavior. The advances are positively related with ROS. The banks having large advances in their portfolio are successful in getting the preference of investors in the stock market. The investors perceive that banks with high advances in their portfolio are more capable to generate value for them. Large advances also show the strength and size of the bank. Although the banks relying heavily on interest income generated from advances face a high credit risk, but investors pay attention to these banks. CAR associates negatively with ROS. This can be the comprehension of investors that banks having high CAR hold their reserves unnecessarily. These reserves do not yield any return for shareholders. The ROS relates positively with GDP and KSE. These two relations are logical. When the economy is flourishing, the investors are able to earn more return on their shares and when the whole market is enjoying growth, the investors reap the fruit and vice versa. However, an important worth noting point is that the relationships of all the antecedents of credit risk are insignificant with both measures of shareholders' value (ROE and 
ROS). This confirms the MM theory according to which the risk management activities are irrelevant with respect to shareholders' wealth maximization as shareholders can manage the risk at their own.

\section{Conclusion}

This study examines the relationship of the factors of credit risk with the shareholders' value. The study confines itself to the banking system of Pakistan. The results of this study reveal that credit risk do not have a significant relationship with the shareholders' value in Pakistani banking system. The results show that banks relying heavily on interest income may face a reduction in their ROE but ROS may experience an increase. LLP has a negative relationship with ROE, but investors take high LLP as a risk taking behavior of the bank, which may increase returns. On the other hand, high CAR helps the banks to increase their ROE, but gives a negative signal to the investors trading in the stock market. The investors perceive the CAR as an unyielding reserve. The results of this study are useful for the policy formulation for both the banks and investors. The banks relying more on interest income must review their policies. The banks need to identify the other sources of income. This identification will help them to diversify, thereby decreasing their reliance on interest income. CAR provides banks a buffer against the losses emanating from risks. The banks should identify the optimal level of CAR, which not only help them to hedge the risk but also avoid the unnecessary holding of their reserves. The findings of this study emphasize that investors should be educated about the credit risk faced by banking system and its consequences. The results reveal that investors are giving preference to the banks having large advances in their portfolio. However, they must understand that these advances can also be the source of risk, which may have devastating effects on the stability of banking system.

\section{References}

Akhtar, S. (2007). Pakistan: changing risk management paradigm - Perspective of the Regulator, ACCA Conference - CFOs: The Opportunities and Challenges Ahead, Karachi.

Ali, F. \& Luft, C. (2002). Corporate risk management: costs and benefits. Global Finance Journal, 13(1), 2938.

Allen, F. \& Santomero, A. M. (1996). The theory of financial intermediation, working paper, Financial Institutions Centre, The Wharton School, University of Pennsylvania, Philadelphia.

Al-Tamimi, H. H. \& Al-Mazrooei, F. M. (2007). Banks' risk management: a comparison study of UAE national and foreign banks. The Journal of Risk Finance, 8(4), 394-409.

Altman, E. I., Caouette, J. B. \& Narayanan, P. (1998). Credit-risk measurement and management: The ironic challenge in the next decade. Financial Analysts Journal, 54(1), 7-11.

Angkinand, A. P., Sawangngoenyuang, W. \& Wihlborg, C. (2010). Financial liberalisation and banking crises: a cross-country analysis. International Review of Finance, 10(2), 263-292.

Baele, L., Jonghe, O. D. \& Vennet, R. V. (2006). Does the stock market value bank diversification? Working paper, Faculty of Economics and Business Administration, Ghent University, Ghent, Belgium.

Baele, L., Vennet, R. V. \& Landschoot, A. V. (2005). Bank risk strategies and cyclical variation in bank stock returns, working paper, Faculty of Economics and Business Administration, Ghent University, Ghent, Belgium.

Baltagi, H. B. (1995). Econometric Analysis of Panel Data, New York: John Wiley and Sons.

Basel Committee on Banking Supervision. (1999). Principles for the management of credit risk, Consultative Paper, Basel: Bank for International Settlements.

Berger, A. \& Humphrey, D. (1997). Efficiency of financial institutions: international survey and directions for future research. European Journal of Operational Research, 98(2), 175-212.

Brooks, C. (2008). Introductory Econometrics for Finance (2nd ed.). New York: Cambridge University Press.

Carty, L. V. (2000). Corporate credit-risk dynamics. Financial Analysts Journal, 56(4), 67-81.

Chaplin, G., Emblow, A. \& Michael, I. (2000). Banking System Liquidity: Developments and Issues. Financial Stability Review, 93-112.

Duca, J. V. \& McLaughlin, M. M. (1990). Developments affecting the profitability of commercial banks. Federal Reserve Bulletin.

Fatemi, A. \& Fooladi, I. (2006). Credit risk management: a survey of practices. Managerial Finance, 32(3), 227-233.

Goodhart, C. E. (2005). Financial regulation, credit risk and financial stability. National Institute Economic Review, 192, 118-129. 
Gujarati, D. N. \& Sangeetha, S. (2004). Basic Econometrics (4th ed.), McGraw-Hill Education (India) Pvt. Ltd.

Honohan, P. \& Laeven, L. (2005). Systemic Financial Crises: Containment and Resolution, New York: Cambridge University Press.

Kao, D. L. (2000). Estimating and pricing credit risk: An overview. Financial Analysts Journal, 56(4), 50-66.

Keasey, K. \& Veronesi, G. (2008). Lessons from the Northern Rock affair. Journal of Financial Regulation and Compliance, 16(1), 8-18.

Lopez, J. A. (2001). Financial instruments for mitigating credit risk. FRBSF Economic Letter.

Miller, S. M. \& Noulas, A. G. (1997). Portfolio mix and large-bank profitability in the USA. Applied Economics, 29(4), 505-512.

Ojo, M. (2010). The growing importance of risk in financial regulation. The Journal of Risk Finance, 11(3), 249-267.

Pagano, M. S. (2001). How theories of financial intermediation and corporate risk-management influence bank risk-taking behaviour. Financial Markets, Institutions and Instruments, 10(5), 277-323.

Pesaran, M. H. \& Schuermann, T. (2003). Credit risk and macroeconomic dynamics. Centre for financial institutions working papers, Wharton School Centre for Financial Institutions, University of Pennsylvania, New York, USA.

SBP. (2009). Guidelines on internal capital adequacy assessment process. State Bank of Pakistan, Karachi.

SBP. (2008). Pakistan is banking system remarkably resilient despite challenging economic environment. SBP's Financial Stability Review, State Bank of Pakistan, Islamabad.

SBP. (2005). Risk Management: Guidelines for Commercial Banks and DFIs. State Bank of Pakistan, Karachi.

SBP. (2010). The state of Pakistan's economy. Central Board of State Bank of Pakistan, State Bank of Pakistan, Islamabad.

Sensarma, R. \& Jayadev, M. (2009). Are bank stocks sensitive to risk management? Journal of Risk Finance, $10(1), 7-22$.

Sufian, F. (2009). Factors influencing bank profitability in a developing economy: Empirical evidence from Malaysia. Global Business Review, 10(2), 225-241. 